\title{
What Makes the Rural Area Resilient?
}

DOI 10.18267/pr.2021.krn.4816.26

\author{
Tibor Zsigmond ${ }^{1}$ - Annamária Zsigmondová ${ }^{2}$ - Renáta Machová ${ }^{3}$ \\ ORCID iD: 0000-0002-2581-55191 , 0000-0002-9128-391X², 0000-0002-7817-01873 \\ zsigmondt@ujs.sk, zsigmondova.annamaria@student.ujs.sk, machovar@ujs.sk \\ 1,3 J. Selye University, Faculty of Economics and Informatics, Department of \\ Management \\ Komárno, Slovakia \\ 2 J. Selye University, Faculty of Economics and Informatics, Department of Economics \\ Komárno, Slovakia
}

\begin{abstract}
The aim of the article is to present rural resilience as a concept. Firstly, we deal with the concept itself, and then turn to the specifics, such as the relationship between ecological, economic and cultural resilience, and sections of economic, social and environmental capital. We also discuss what distinguishes the resilient region from the nonresilient. At the end of our article, we also deal with the changes during the "coronavirus epidemic," in which we briefly describe a specific project that is currently underway.
\end{abstract}

Keywords: resilient, rural resilience, ecological resilience, economic resilience, cultural resilience

JEL Classification codes: O18, P25, R10

\section{INTRODUCTION}

The term "resilience" has a Latin origin from "salire" which means „jump". The prefix "re" corresponds to the term "backward". In summary, "re-salire" $\rightarrow$ "re-silire" means "jumping back", but it can also be interpreted as "stretch, dissolve but not break". The term was first used in physics, in connection with the resilience of the metal to the shock. Later, the terminology was also used in psychology. It was observed that children have an ability that allowed them to regain their original physical and mental condition and balance in a short period of time after experiencing a difficult situation. Today, the term is used in association both with children and adults. Psychological resilience is the ability to mentally or emotionally cope with a crisis or return to a precrisis status quickly. Psychological resilience can be developed. The individuals will find it easier to cope with traumas (loss of family member, health problems, loss of job, etc.). Garmezy (1973) is one of the pioneers in the field of resilience research. According to him, resilience is an ability that enables and maintains adaptive behavior after experiencing trauma, tragedy or abuse (Masten, Powell, 2003; Windle, 2011).

Since its introduction, the concept "resilience" has appeared and has been used as a scientific term in ecology, food aid, famine, resource management and health. The term "resilience" is used not only referring to individuals. Resilience in general is a flexible resistance, a reactive ability of an individual, organization, ecosystem or a kind of material to adapt successfully to adverse, shock-like external influences. In other words, resilience is the ability of an area to retain its basic functions and adapt to a new situation with single, repetitive, or continuous influences. (Wilson, 2010; McManus et al., 2012; Robinson, Carson, 2016; Resilience, online). 


\section{LITERATURE REVIEW}

In modern ecology, the concept of ecological resilience plays an important role. It can be defined as a system capable of absorbing various shocks, so that the previously existing functions, the existing structure and the feedback remain viable. The term "resilience" first appeared in an ecological context in the work of Holling (1973). Despite the fact that the rural areas are facing rapid changes and uncertainties (agriculture, forestry, and landscape) that have significant future impact, the concept of "resilience" is still rarely used in connection with rural development. It can therefore be stated that little attention was addressed to the resilience of these areas (Heijman, Hagelaar, van der Heide, 2007; Schouten, van der Heide, Heijman, 2009; Robinson, Carson, 2016, Jašková, 2019).

The rural area can be considered as a complex socio-ecological system. A sufficient quantity and quality scientific literature on the resilience of these systems has been published. It is important to emphasize that within socio-ecological systems, the principles of resilience have rarely been analyzed from the perspective of specific rural aspects. Rural resilience can be best defined as the ability of a rural region to adapt to changing external conditions. It has to be achieved to maintain a satisfactory standard of living - prosperity. This also includes the ability to "recover" from management problems. The resilience of the rural area determines the extent to which a given area has the ability to adapt to changes before organizing around new structures and processes. It also expresses how the rural area is able to simultaneously balance ecosystem, economic and cultural functions, thus being able to cope with the impact of these factors. The ecological, economic and cultural systems are increasingly interconnected, the intensity and extent of interactions between these systems are increasing. These three forms of resilience are thus interconnected. The rural resilience is based on ecological, economic and cultural resilience. These three forms of resilience are thus interconnected. This can be easily illustrated by the following figure.

Fig. 1 Rural resilience - relationship between the ecological, economic and cultural resilience

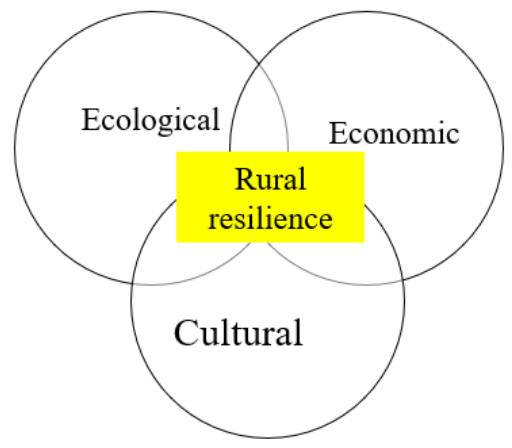

Source: own processing according to Heijman, Hagelaar, van der Heide, 2007

Based on the figure, it can be assumed that a change in one of the areas of resilience can affect the resilience of other areas. If a region is economically not resilient (sensitive to economic shocks, decrease of prosperity, a sudden significant rise of interest rates, increasing job insecurity), the population is gradually moving away and the region becomes vulnerable. Due to the increased vulnerability, even smaller problems can result in chaos and crisis in the rural system. If the region is ecologically not resilient, conditions for agriculture and green services can deteriorate. This can increase the vulnerability of the region as well. Cultural resilience is also a necessary condition for rural resilience, as it ensures that an adequate level of human capital is retained in the region. This can also contribute to vulnerability of the rural system. Building resilience should be an integral part of rural planning (Heijman, Hagelaar, 
van der Heide, 2007; Schouten, van der Heide, Heijman, 2009; Šimo, Mura, Žufan, 2012; Robinson, Carson, 2016, Mura, Kljucnikov, 2018).

Huylenbroek et al. (2007) and Chaskin (2008) also outlined a similar approach in their work. They emphasized the importance of the interaction of social, economic and environmental processes. According to them, community resilience should be seen as a positive and adaptive response to disadvantages, if resilient actors (individuals, systems) can utilize economic, social and environmental capital to successfully adapt and thus avoid or mitigate the negative consequences of similar threats. In this term, resilience can have a preventive character (e.g., can prevent negative outcomes by developing coping strategies) or it can facilitate recovery after a traumatic event or disaster. Resilience means whether a system is able to absorb shocks, respectively, it will be able to recover into a functioning system again. Vulnerability can be assessed in terms of the exposure and sensitivity of the system that is generally unable to cope with the risks and threats or the slow or catastrophic changes that ultimately lead to disappearance of the system or certain parts of it. The following figure illustrates that the interlacing of economic, social and environmental capital creates various multifunctional "parts". The rural systems, where only two areas (capital) are developed can only be characterized as "moderately" multifunctional, while those rural communities that have only one (or have no) well-developed capital are "weakly" multifunctional (in extreme cases monofunctional). (Bobenič Hintošová, Bruothová, Vasková, 2020; Happ, Ivancsóné Horváth, Kupi, 2020)

Fig. 2 Multifunctional quality - intersection of economic, social and environmental capital

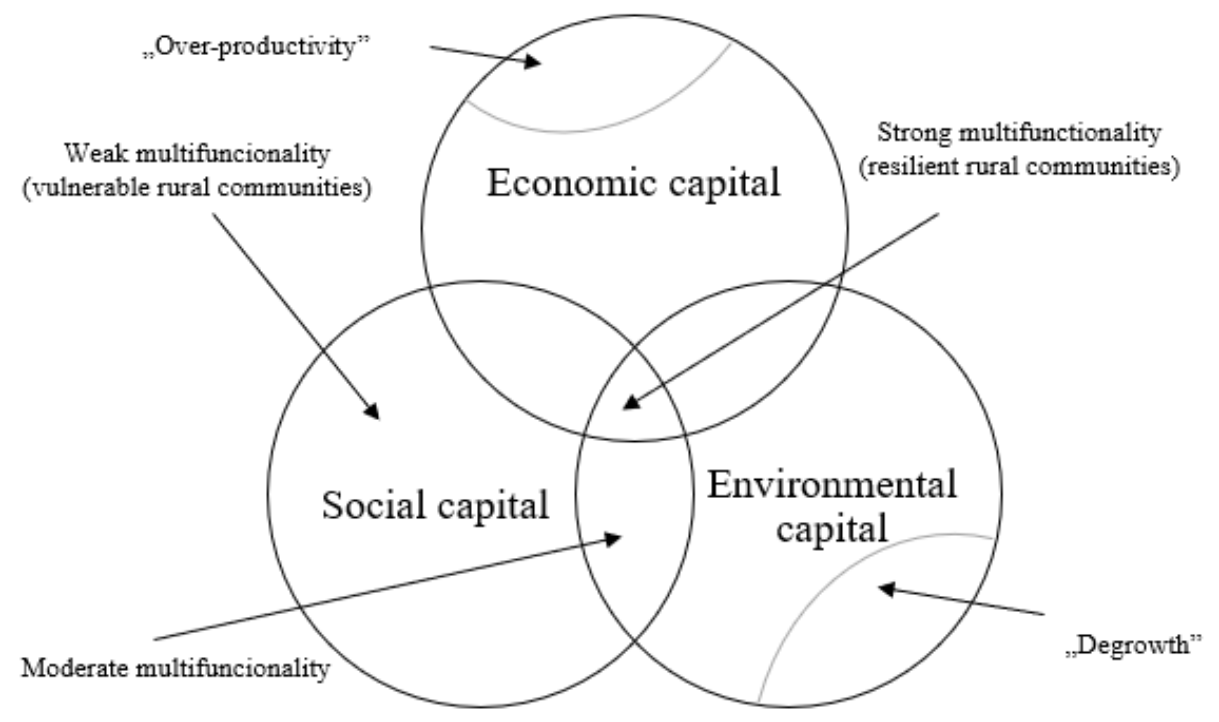

Source: own processing according to Heijman, Hagelaar, van der Heide, 2007 and Van Huylenbroek et al. (2007)

The figure also highlights that the conceptual fields of both over-productivity and degrowth can be placed at the "extreme end" of the economic and environmental capital. Overproductivity was addressed by several authors, Halfacree (2007) is one of the most known addressing the issue. According to him, productivity is the primary aspect, but less importance is gained by the moral dimension. Latouche (2006) is one of the leading theorists of the degrowth movement. According to Mészáros (2019, p. 259), degrowth is a new economic paradigm recommended for developed countries that can result in long-term ecological sustainability of our planet and establishment of fair societies. The first international "degrowth conference" was held in 2008 in Paris. The methodological appeal of this framework is that it 
can be applied to any rural area as well as it is highly independent (Huylenbroek et al., 2007; Chaskin, 2008; Wilson, 2010; Kovách, 2012; Alabán, 2013, Simionescu et al., 2021).

Based on this, the resilience of the rural community can be considered as a balance between the economic, social and environmental needs of the community. This kind of resilience means that communities are able to successfully cope with endogenous and exogenous changes. Such resilience can be expressed through the speed, robustness and ingenuity of a particular community that helps to find the ways to address internal and external challenges to multifunctional quality at the intersection of economic, social and environmental capital. Resilience can be detected on the level of households and individuals. General resilience of the rural community is shaped by economic, social and environmental activities, and formed by the responses of individuals and households. One of the main aspirations of policy makers should be to maximize the resilience to help local communities in their fight for survival. In order for rural communities to be economically, socially and environmentally sustainable and resilient, it is necessary to develop multifunctional characteristics (Huylenbroek et al., 2007; Chaskin, 2008; Wilson, 2010; Kovách, 2012; Alabán, 2013).

\section{METHODOLOGY}

Our research results are based on examining secondary data. The article is addressing the concept of rural resilience in details. The content of this chapter is based on the findings of experts. The further parts of the article process secondary data to differentiate the resilient region from the less resilient. We would like to introduce a model that incorporates the findings of published research. Following this, we would like to present the impact of COVID-19 pandemic on the resilience of the countryside and introduce the project "RURITAGE" funded by the EU. The primary project objective is the sustainable development of local heritage to contribute to regional and community development.

\section{RESULTS AND DISCUSSION}

Based on the reviewed scientific literature, the rural resilience is influenced by 3 main "areas" - economic, social and environmental. These "areas" possess a certain amount of capital. There are developed and less developed factors and components within the capital (Pretty, 1995; 2002; Parnwell, 2007; Van Huylenbroek et al., 2007; Noe, Fjelsted, Langvad, 2008; Chaskin, 2008); Cutter et al., 2008; Rigg et al., 2008; Wilson, 2010; Kovách, 2012; Alabán, 2013)

In the case of economic capital, the economic prosperity in rural areas is the most important factor. It is also important to have a diverse source of income and low dependence on external sources. The more diverse sectors businesses in the region come from, the more competitive the region is. It is also important to consider the level of integration into the capitalist system as well as happiness as a positive factor. Economically less resilient areas are indebted, heavily dependent on agricultural activity or other external resources, have poor infrastructure and developed dependence on import of food produce (Pretty, 1995; 2002; Parnwell, 2007; Van Huylenbroek et al., 2007; Noe, Fjelsted, Langvad, 2008; Chaskin, 2008); Cutter et al., 2008; Rigg et al., 2008; Wilson, 2010; Kovách, 2012; Alabán, 2013).

A rural community will be socially resilient if there is strong social interaction between the individuals of the community. Such regions have an adequate number of educational facilities, good hygienic conditions and offer a wide range of services. There is efficient communication between the interest groups. Socially resilient communities are open-minded, providing equal opportunities for women and members of ethnic minority groups. Land ownership regulations 
are transparent and government structures are strong. The goals and direction of development are clearly set. Less resilient regions are characterized by low life expectancy, high levels of mortality and the young are leaving the region. The area is characterized by a limited variety of services. The leadership and control in the region are weak. Communication between the interest groups is weak, inequalities can be detected. The region is characterized by less transparency in land ownership, the government structures are weak. The goals and development direction are unclear (Pretty, 1995; 2002; Parnwell, 2007; Van Huylenbroek et al., 2007; Noe, Fjelsted, Langvad, 2008; Chaskin, 2008); Cutter et al., 2008; Rigg et al., 2008; Wilson, 2010; Kovách, 2012; Alabán, 2013).

If environmental capital is taken into account, the regions with high level of biodiversity, adequate quality and quantity of water will count resilient. The management of natural resources and soil management is sustainable - mainly multifunctional - the agricultural yield can be predicted. The regions with poor soil quality, desertification and salinization are less resilient. The region is characterized by poor water quality and inadequate resources of water. The agricultural yield in these regions is uncertain and unpredictable (Pretty, 1995; 2002; Parnwell, 2007; Van Huylenbroek et al., 2007; Noe, Fjelsted, Langvad, 2008; Chaskin, 2008); Cutter et al., 2008; Rigg et al., 2008; Wilson, 2010; Kovách, 2012; Alabán, 2013).

Tab. 1 Characteristics of resilient and less resilient regions

\begin{tabular}{|c|c|c|c|}
\hline & \multicolumn{2}{|c|}{ Development level of factor (capital) } \\
\hline & & Resilient & Non-resilient \\
\hline \multirow{16}{*}{ 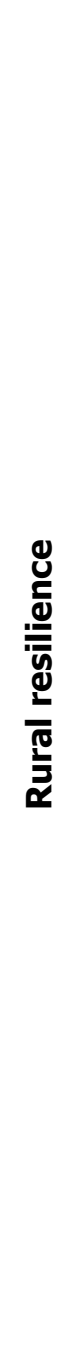 } & \multirow{6}{*}{ 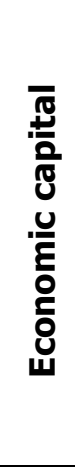 } & Economic prosperity & Poverty / debt \\
\hline & & Diverse (multiple) sources of income & $\begin{array}{l}\text { High dependence on agricultural } \\
\text { production }\end{array}$ \\
\hline & & Low dependence on external resources & High dependence on external resources \\
\hline & & Multifunctional businesses & Food import \\
\hline & & $\begin{array}{l}\text { Integration into the global capitalist } \\
\text { system }\end{array}$ & Poor infrastructure \\
\hline & & Happiness & \\
\hline & \multirow{10}{*}{ 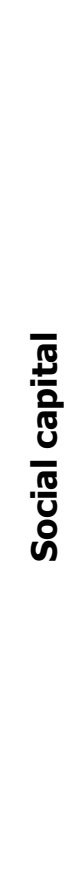 } & $\begin{array}{l}\text { Strong connections, interactions between } \\
\text { the actors }\end{array}$ & Young leaving the country \\
\hline & & Training and education opportunities & Poor range of services \\
\hline & & Good health and hygiene & Lack of leadership \\
\hline & & Wide range of services & Lack of control over the life of community \\
\hline & & $\begin{array}{l}\text { Good communication between the } \\
\text { interest groups }\end{array}$ & $\begin{array}{l}\text { Low life expectancy and high mortality } \\
\text { ratio }\end{array}$ \\
\hline & & $\begin{array}{l}\text { Involvement of women and ethnic } \\
\text { minorities }\end{array}$ & $\begin{array}{l}\text { Poor communication between the interest } \\
\text { groups }\end{array}$ \\
\hline & & Open-minded communities & $\begin{array}{l}\text { Inadequate female involvement, lack of } \\
\text { involvement of minorities }\end{array}$ \\
\hline & & Transparent land ownership regulation & $\begin{array}{l}\text { Less transparent land ownership } \\
\text { regulation }\end{array}$ \\
\hline & & $\begin{array}{l}\text { Rural stakeholders to determine } \\
\text { development directions }\end{array}$ & $\begin{array}{l}\text { General dissatisfaction with the goals of } \\
\text { the rural community }\end{array}$ \\
\hline & & Strong governance structures & Weak governance structures \\
\hline
\end{tabular}




\begin{tabular}{|c|c|c|}
\hline \multirow{6}{*}{ 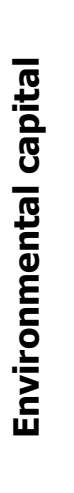 } & High level of biodiversity & Poor quality soil \\
\hline & $\begin{array}{l}\text { Good quality and adequate quantity of } \\
\text { water }\end{array}$ & Desertification \\
\hline & Sustainable land management & Salinization \\
\hline & Predictable agricultural yield & $\begin{array}{l}\text { Poor water quality and inadequate } \\
\text { amount of water source }\end{array}$ \\
\hline & $\begin{array}{l}\text { Sustainable management of } \\
\text { environmental resources }\end{array}$ & Unpredictable agricultural yield \\
\hline & Multifunctional environmental resources & \\
\hline
\end{tabular}

Source: own processing according to Pretty (1995; 2002); Parnwell (2007); Van Huylenbroek et al. (2007); Noe, Fjelsted, Langvad (2008); Chaskin (2008); Cutter et al. (2008); Rigg et al. (2008); Wilson (2010)

There are several factors that can affect the resilience of an area, the most important are presented in the table above. There is no rural region that can be characterized only by positive factors, there are also some negative, unavoidable factors that need to be offset by positive ones. The more positive factors the certain region is characterized by, the more adaptable the region will be.

RURITAGE is a four-year-long EU funded research project, launched in June 2018, which strives to enable rural regeneration through utilizing the heritage of the area. The main goal is to sustainably enhance local heritage to develop regional communities. Further objective is the regeneration of the rural areas through the "Systemic Innovation Areas"- SIA framework, which identifies the unique heritage potential of the rural communities. The approved SIAs are the pilgrimage, resilience, sustainable local food production, integrated landscape management, migration, art and festivals (RURITAGE project, online).

The rural areas tell us the story of thousands years of cooperation between nature and society. These places embody the unique example of cultural and natural heritage that have to be preserved but also recognized as communities of sustainable development. RURITAGE establishes a rural regeneration paradigm able to transform rural areas into sustainable development demonstration "laboratories" to introduce the natural and cultural heritage as an engine for regeneration (RURITAGE project, online).

Fig. 3 Systematic Innovation Areas - SIA

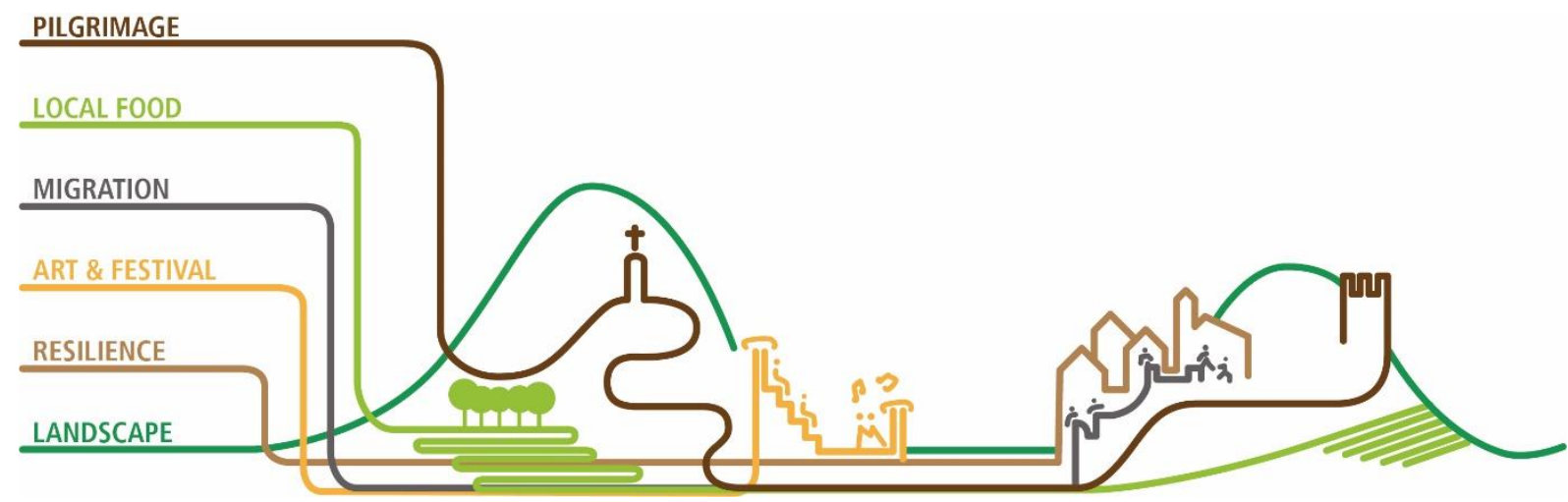

Source: Ruritage Project (online)

Rural areas face chronic economic, social and environmental problems around the world. This can result in unemployment, migration, depopulation, marginalization or the loss of cultural, 
biological and landscape diversity. The project points out that the challenges of rural areas can be reversed by exploiting the potential of natural and cultural heritage (RURITAGE project, online).

The website of the project warns the attention of the visitor to find solutions and provide ideas to combat the consequences of the coronavirus pandemic. Such an unexpected situation is a challenge not only for societies and the economy as a whole, but also for individuals and communities. COVID-19 not only halted the critical development phase of rural communities "Replicators and Role Models", but also generated a real test for the resilience of individuals and the community. The "Role Models" have regenerated by utilizing the natural and cultural heritage of the area. The good practices of these role model areas are analyzed and joined to the chosen rural territories, the so-called Replicators. Each Replicator works predominantly in one of the identified Systemic Innovation Areas but will be influenced also by some other SIAs. These replicators represent the local communities in rural areas, where heritage-driven reconstruction strategies are already being developed, although they need support to develop their skills, knowledge or capacity. The knowledge and skills gained from the experience of Role Models are transferred to Replicators through a participatory planning process. This allows the strategies of the "Role Models" to be customized and adapted to the specific needs and challenges of "Replicators" (RURITAGE project, online; Rural Resilience Actions, 2020, online).

The crisis is attacking the rural areas as well, as these areas are faced by challenges influenced by the problem of less available resources and deepening isolation. The rural communities are struggling to find customized solutions to their already fragile and vulnerable environment. At the same time, the value of local resources, cultural and natural heritage, the value of human capital, mutual support and networks, better cooperation and solidarity have strengthened. The main objective is to achieve a strengthened resilience (Rural Resilience Actions, 2020, online).

As a part of the project communication activity, a project website was created that allowed the visitors to submit their solution proposals supporting the success of the project. The initiative started within the project is "Rural Resilience in times of COVID-19". Initiatives and measures to be taken are expected to be proposed connected to sustainability, cultural and natural heritage, the most important innovation areas - pilgrimage, resilience, sustainable local food production, integrated landscape management, migration, arts and festivals. A questionnaire format, containing 11 questions was created to submit the proposals for improvement. The questionnaire contained open-ended questions to motivate the respondents to formulate opinions, ideas or propose solutions. The questionnaire contains only 2 closed questions. In the first, that area should be indicated by the respondents - pilgrimage, resilience, sustainable local food production, integrated landscape management, migration, art and festivals - which is closely related to the proposal for improvement. A closed question also appears at the end of the questionnaire, where the respondents agree their data provided to be processed. The questionnaire is anonymous (Rural Resilience Actions, 2020, online).

\section{CONCLUSION}

The main goal of this article is to introduce the concept of "rural resilience", which is relatively less addressed by the domestic and Central-European scientific literature. The concept covers the resilience of rural areas, an enormously important issue in the current rapidly changing and developing environment. A developed rural area has a capacity to cope also with the biggest changes even during the period of pandemics. However, COVID-19 brought difficult challenges to face in the society. It has already made the society flexible and prepared in certain ways. If we would like to examine the resilience of a rural area, it is necessary to examine the ecological, economic and cultural aspects of the area. These 3 areas are closely 
related. If the rural area is not economically resilient, the population will leave the area, and the region will become vulnerable. If the region is not resilient ecologically, the conditions of agricultural and green services can deteriorate. Building resilience should be an integral part of rural planning.

Following another approach, community resilience should be seen as a positive, adaptive response to disadvantages. If resilient actors (individuals, systems) can utilize economic, social and environmental capital to adapt successfully, will succeed to avoid the negative consequences of potential threats. Rural resilience is a balance of economic, social and environmental needs of the community. Economic well-being is the most important economic capital, which is associated with a diverse source of income and low dependence on external sources. The more diverse the companies in the region are, the more competitive the region is. Socially resilient regions have adequate access to training and education opportunities, adequate hygienic conditions, good communication and wide range of services. Environmentally resilient regions are characterized by high biodiversity, adequate and good quality water as well as sustainable soil management.

RURITAGE project is benefiting the rural areas, although launched before COVID-19, the project has successfully adapted to the current situation. Implementation of similar projects is needed, so that rural areas do not lag behind in the development of urban areas. These areas possess many potentials that can be utilized to strengthen their position in the society.

The areas of development receive an unequal, different emphasis in each region. In each case, the location plays a big role. The opportunities offered by each natural endowment are important, but at the same time, for example, the role of transport hubs (motorways, railway junctions, airports, etc.) that determine the opportunities of the area. In addition to these, there are factors such as history and the neighboring area. These factors are (mostly) hardly affected by the area itself. One can only adapt to the natural conditions by noticing and taking advantage of the opportunities offered. Some disadvantages should be tried to be reduced or made insignificant - for example, by focusing on other areas. It is necessary to analyze the situation and identify the obstacles that have prevented the development. Once these have been identified, they need to be removed. It is unfortunately that sometimes the representatives of an area are replaced after the elections and the new board sets completely opposite goals in their new program, ignoring the successful plans and insights of previous years.

\section{ACKNOWLEDGEMENT}

The research team would like to express its gratitude to our institution, J. Selye University, supporting the research activity of the team.

\section{REFERENCES}

Alabán, P. (2013). Kovách Imre: A vidék az ezredfordulón. A jelenkori magyar vidéki társadalom szerkezeti és hatalmi változásai. Metszetek, 2(3), 299-307.

Bobenič Hintošová, A., Bruothová, M., \& Vasková, I. (2020). Does Foreign Direct Investment Boost Innovation? The Case of the Visegrad and Baltic Countries. Quality Innovation Prosperity /Kvalita Inovácia Prosperita, 24(3), 106-121. https://doi.org/10.12776/qip.v24i3.1519

Chaskin, R. J. (2008). Resilience, community, and resilient communities: conditioning contexts and collective action. Child Care in Practice, 14(1), 65-74. https://doi.org/10.1080/13575270701733724 
Cutter, S. L., Barnes, L., Berry, M., Burton, C., Evans, E., Tate, E., \& Webb, J. (2008). A placebased model for understanding community resilience to natural disasters. Global Environmental Change, 18(4), 598-606. https://doi.org/10.1016/j.gloenvcha.2008.07.013

Garmezy, N. (1973). Competence and adaptation in adult schizophrenic patients and children at risk. Schizophrenia: The first ten Dean Award lectures. New York: MSS Information Corporation.

Halfacree, K. (2007). Trial by space for a 'radical rural': Introducing alternative localities, representations and lives. Journal of Rural Studies, 23(2), 125-141. https://doi.org/10.1016/j.jrurstud.2006.10.002

Happ, É., Ivancsóné Horváth, Zs., \& Kupi, M. (2020). Digitális eszközök és módszerek használatának marketingszempontú feltáró elemzése a magyar turisták körében. Turizmus Bulletin, 20(2), 4-13.

Heijman, W., Hagelaar, G., \& van der Heide, M. (2007). Rural Resilience As A New Development Concept. In Development of Agriculture and Rural Areas in Central and Eastern Europe (383-396). Novi Sad: Serbian Association of Agricultural Economists. https://doi.org/10.22004/ag.econ.162359

Holling, C.S. (1973). Resilience and Stability of Ecological Systems. Annual Review of Ecology and Systematics, 4, 1-23. https://doi.org/10.1146/annurev.es.04.110173.000245

Jašková, D. (2019). Assessment of social development in Slovakia in the context of human resources. Central European Journal of Labour Law and Personnel Management, 2 (2), 21-32. http://doi.org/10.33382/cejllpm.2019.03.02

Kovách, I. (2012). A vidék az ezredfordulón. A jelenkori magyar vidéki társadalom szerkezeti és hatalmi változásai. Budapest: Argumentum Kiadó.

Latouche, S. (2006). Le pari de la décroissance. Paris: Fayard.

Masten, A. \& Powell, J. (2003). A Resilience Framework for Research, Policy, and Practice. In Resilience and Vulnerability: Adaptation in the Context of Childhood Adversities (1-26). Cambridge: Cambridge University Press.

McManus, P., Walmsley, J., Argent, N., Baum, S., Bourke, L., Martin, J., Pritchard, B., \& Sorensen, T. (2012). Rural Community and Rural Resilience: What is important to farmers in keeping their country towns alive? Journal of Rural Studies, 28(1), 20-29. https://doi.org/10.1016/j.jrurstud.2011.09.003

Mészáros, S. (2011). Nemnövekedés: egy új gazdasági paradigma európai fejleményei. Gazdálkodás, 55(3), 259-265.

Mura, L. \& Kljucnikov, A. (2018). Small Businesses in Rural Tourism and Agrotourism: Study from Slovakia. Economics \& Sociology, 11 (3), 286-300. https://doi.org/10.14254/2071789X.2018/11-3/17

Noe, E., Fjelsted, A.H., \& Langvad, A.M. (2008). A polyocular framework for research on multifunctional farming and rural development. Sociologia Ruralis, 48(1), 1-15. https://doi.org/10.1111/j.1467-9523.2008.00451.x

Parnwell, M.J. (2007). Neolocalism and renascent social capital in northeast Thailand Environment and Planning D. Society and Space, 25(6), 990-1014. https://doi.org/10.1068/d451t

Pretty, J.N. (1995). Regenerating agriculture: policies and practice for sustainability and selfreliance. London: Earthscan.

Pretty, J.N. (2002). Agri-culture: reconnecting people, land and nature. London: Earthscan. 
Resilience. Retrieved 07 February 2021, from https://www.etymonline.com/word/resilience.

Reziliens. Retrieved 07 February 2021, from https://idegen-szavak.hu/reziliens.

Rigg, J., Veeravongs, S., Veeravongs, L., \& Rohitarachoon, P. (2008). Reconfiguring rural spaces and remaking rural lives in central Thailand. Journal of Southeast Asian Studies, 39(3), 355-81.

Robinson, G.M. \& Carson, D.A. (2016). Resilient communities: transitions, pathways and resourcefulness. The Geographical Journal, 182(2), 114-122. https://doi.org/10.1111/geoj.12144

Ruritage Project. Retrieved 07 February 2021, from https://www.ruritage.eu/project/.

Rural Resilience Actions in times of COVID-19. (2020). Retrieved 07 February 2021, from https://www.ruritage.eu/news-events/news/ruralresilienceactions-covid-19/\# .

Schouten, M., van der Heide, M., \& Heijman, W. (2009). Resilience of Social-Ecological Systems in European Rural Areas: Theory and Prospects. In The Role of Knowledge, Innovation and Human Capital in Multifunctional Agriculture and Territorial Rural Development (117-130). Belgrade: EAAE.

Simionescu, M., Bilan, Y., Zawadzki, P., Wojciechowski, A., \& Rabe, M. (2021). GHG Emissions Mitigation in the European Union Based on Labor Market Changes. Energies, 14(2), 1-13. https://doi.org/10.3390/en14020465

Šimo, D., Mura, L., \& Žufan, P. (2012). Manažment marketing výroby a odbytu zeleniny v podmienkach Slovenskej republiky. Acta Oeconomica Universitatis Selye, 1(2), 185-196.

Van Huylenbroek, G., Vandermeulen, V., Mettepenningen, E., \& Verspecht, A. (2007). Multifunctionality of agriculture: a review of definitions, evidence and instruments. Living Reviews in Landscape Research, 1(3), 5-43. http://dx.doi.org/10.12942//rlr-2007-3

Wilson, G. (2010). Multifunctional 'quality' and rural community resilience. Royal Geographical Society, 35(3), 364-381.

Windle, G. (2011). What is resilience? A review and concept analysis. Reviews in Clinical Gerontology, 21(2), 152 - 169. https://doi.org/10.1017/S0959259810000420 